\title{
NGROWOT URGENCY (CASE STUDY OF SANTRI ISLAMIC BUILDING SCHOOL OF JAGAD 'ALIMUSSIRRY) IN ACHIEVING PEACE OF THE SOUL
}

\author{
N L I Puspita ${ }^{1}$, H Aliyah ${ }^{2}$ \\ ${ }^{1}$ Islamic Building School of Jagad 'Alimussirry Surabaya, Indonesia \\ ${ }^{2}$ Science Department, Universitas Negeri Surabaya \\ Email: Laylipus77@gmail.com
}

\begin{abstract}
In this life, there are so many difficulties in life that make the heart anxious and make the heart uneasy, therefore it is necessary to get closer to Allah SWT so that the heart becomes calm, one of which is by doing tirakat, one of which is by ngrowot. This study aims to determine how peace the soul of Jagad 'Alimussirry islamic buildingschool students, to know the effect of tirakat ngrowot in achieving peace of mind, and to find out how important the tirakat ngrowot is carried out by students of Jagad 'Alimussirry islamic buildingschool in achieving peace of mind. This research is a descriptive qualitative research conducted by means of field observations and interviews with Jagad 'Alimussirry islamic buildingschool students who do tirakat ngrowot. The results of this study were the students of the Jagad 'Alimussirry islamic buildingschool Students do tirakat ngrowot sincerely and are happy to carry out the duties of the kyai's brother. Initial conditions or problems experienced by students of the Jagad 'Alimussirry islamic buildingschool are responsibility issues, campus problems and the cottage environment. One of the impacts that can be seen during or after doing tirakat ngrowot is being a person who is resilient, patient, and can apply the Jagad'Alimussirry Islamic Building school motto in everyday life. And also getting blessed to leave as it is facilitated in education and looking for work.
\end{abstract}

Keywords: tirakat ngrowot; peace of mind; blessed.

\section{INTRODUCTION}

Life in today's civilization is increasingly heavy and feels cruel, making everyone try to fight harder and never give up to conquer it (Nietzsche, 1998). From this hard work, people can get what they aspire to and some fail to get it.On the way to achieving success, he is often faced with life's problems. The problem is to feel that what is at present is something that is unexpected, disappointing, dangerous and can destroy life in the future. Whose soul would not be shaken when faced with this condition? could survive this situation but the soul in reality is always shaken. It is also possible to be influenced or become a person who is always in torment mentally and physically. These feelings turn out to make us human beings in pain; become anxious easily, often feel depressed, depressed, hysterical in looking at life and become a mentally disturbed person. Or even become a life loser; namely choosing the path of suicide so that the problems in this world can be replac forever. Based on the results of preliminary observations of Jagad 'Alimussirry islamic buildingschool students, many experienced feelings of anxiety, and so on. This is due to the large number of college assignments, internal problems with the organization or with other students, missing homes, financial problems, and so on. 
Jagad 'Alimussirry islamic buildingschool also teaches the science of Fiqh, Hadith, Tawheed, Al-Quran Tafsir, Nahwu, Sharaf. In addition to teaching the above sciences, Jagad 'Alimussirry islamic buildingschool also provides assignments and requirements to pass, namely carrying out several riyadhoh activities. One form of riyadhoh is ngrowot. Ngrowot, namely not allowed to eat rice / rice, white rice can be replaced with corn rice or something else. Ngrowot is a practice of riyadhoh as a form of zuhud behavior, which is to let go of dependence on worldly or material dependence. Sufis teach not to depend on worldly things through this spiritual teaching, one is taught to achieve blessings and happiness that are eternal, because positive feelings do not arise from worldly things but from a calm heart (Martokusumo, 2011) .

Therefore, doing riyadhoh activities to be close to Allah SWT and get peace of mind. The closer the santri are to God and the more their worship, the more they will be able to face disappointments and difficulties in life, on the other hand, the farther a person is from religion, the more difficult it will be for him to find inner peace (Dara Jagad 'Alimussirry buildingschoolt, 1982). This research was conducted to find out how urgent it is to raise students of Jagad 'Alimussirry islamic buildingschool in achieving peace of mind.

\section{METHOD}

This research uses qualitative research, which is a scientific research that aims to understand a phenomenon in a natural social context by promoting a deep communication interaction process between the researcher and the phenomenon being studied (Herdiansyah 2018 : 18) The research subjects to be selected were 7 male students, four students, and six female students. All of which are or have been doing ngrowot. The total number of students from Jagad 'Alimussirry buildingschool is 126 students. The number of male students is 37 while the female students are 89.
Datacollection techniqus in this study by taking several steps, namely observation, and interviews. Observation is a data collection technique by means of direct observation, to obtain data clearly and be able to know the real conditions in the field. While the interview is the process of obtaining information for research purposes by means of question and answer face-to-face between the interviewer and the respondent.

\section{RESULTS AND DISCUSSION}

A. Some Tirakat that must be done by Santri Jagad 'Alimussirry Islamic buildingschool as a graduation requirement.

Some of the tirakat that students must do to complete S1 at Jagad 'Alimussirry islamic buildingschool:

1. Doing fast for 3 days (Tuesday, Wednesday, Thursday) and not eating animate things by reading lau anzalna (Surah Al Hasyr: 21-24) at midnight after the evening prayer.

2. Doing fast for 3 days (Tuesday, Wednesday, Thursday) and not eating animate things by reading laqodja (Surah At Taubah: 128-129) at midnight after the evening prayer.

3. Doing fast for 3 days (Tuesday, Wednesday, Thursday) and not eating animate things by reciting 'asallah (Surah An - nisa: 84) at midnight after evening prayers.

4. Doing fast for 3 days (Tuesday, Wednesday, Thursday) and not eating animate ones by reading bardannas at midnight after evening prayers.

5. Doing fast for 3 days (Tuesday, Wednesday, Thursday) and not eating animate things by reading wa idzaa bathosum at midnight after night prayers.

6. Doing fast for 3 days (Tuesday, Wednesday, Thursday) and not eating other than plain rice and plain water (fasting mutih) by reciting allahumma 
mu'allina at midnight after evening prayer.

7. Doing 3 days of fasting (Tuesday, Wednesday, Thursday) and not eating other than plain rice and water (mutih fasting) by reading allahul kahfi at midnight after evening prayer.

8. Fasting Monday, Thursday 7 times

9. Doing weton fasting 7 times

10. Doing daud fast for at least $1-3$ months.

Some of the tirakat that students must do to complete their Masters in Alimussirry Universe:

1. Doing fasting 4 months after Ramadan and wiridnya

2. Doing repentant baths for 40 days or bathing in 9 lapan springs

3. Doing a bath in the sea

4. Eat corn rice (ngrowot) for at least 1 year

5. Pilgrimage to wali - guardians of Allah

6. Perform tawasul after praying that the $\mathrm{Al}$ - Fatihah is 199 at least 1 year

7. Drink floral water

B. The Origin of Ngrowot According to KH. Dr. Djoko Hartono, S.Pd, S.Ag, MM as founder and caretaker of Jagad 'Alimussirry islamic buildingschool.

The Jagad 'Alimussirry islamic buildingschool Order actually stands with the background of seeking the pleasure of Allah in order to carry out the mandate of the Kyai / Ulama '/ Teachers who are there to continue his struggle as the heir to the prophet, educate the public, revive positive Sufism (neo Sufism), become a means of the path to Kamil's people., and achieve makrifat and the degree of guardian of Allah. For this reason, the presence of the Jagad 'Alimussirry islamic buildingschool Order is not excessive if then with his permission, will and power and blessing it can be a solution for the problems of the people everywhere, especially in the Metropolitan city of Surabaya.
Based on the book Amaliyah Thariqah Jagad islamic "Alimussirry buildingschool, the establishment of TJA (Thariqah Jagad 'Alimussirry) and Jagad 'Alimussirry Islamic Building School the establishment of TJA and Jagad 'Alimussirry Islamic Building school was actually inspired by the mandate of Mbah KH. Abdullah, Mbah Kyai Ahmad Fauzan (Sweep Jagad 'Alimussirry islamic buildingschool), Mbah KH. Thoyyib (Abah Thoyyib) Sumengko. Before he died, he secured the TJA / Jagad 'Alimussirry Islamic Building School caregiver alfakir to continue his struggle and the mandate given by his teacher to sit as people, to establish a building school.

Based on interviews with the caregivers of the Jagad 'Alimussirry buildingschool Alimussirry Islamic BuildingSchool, namely Dr. KH. Djoko Hartono S.Ag, M.Ag, M.M regarding the origin of ngrowot "Kanjeng of the prophet is a lot of people who are reluctant. The staple food of the Arabs is wheat, but he - he eats dates, fruits. Including the Prophet Ibrahim to pray that his descendants will be overflowed with a fortune of fruit to become food. Because to become a prophet, these were not ordinary people but extraordinary people, so the prophets used to eat a lot of fruits, this is if in Jagad 'Alimussirry buildingschoolvanese the name is ngrowot eating fruits or avoiding staple foods (polo pendem, vegetables) naah, the origin is ngrowot, not inconsequential, but indeed the term was not uttered by the prophet, only in practice."

The caretaker of the Jagad "Alimussirry islamic buildingschool has also done tirakat ngrowot. Motivation to do ngrowot is because it is motivated by Mbah KH. Abdullah SaJagad 'Alimussirry buildingschoold once told me that someone named Angon in the middle of the forest saw Wali Songo build a Demak mosque in the middle of the forest and finally Angon approached Wali Songo and asked Walli Songo, then let Angon not ask Wali Songo. Angon was given white rice and 
chicken side dishes that were still hot, and finally Angon ate it, after that Angon was told by Wali Songo to check whether his horse was still there or missing, after Angon checked and returned to Wali Ono suddenly everything was gone, only trees Forest. From the story, it is said that the conclusion is that if Allah SWT wants to open his hiJagad 'Alimussirry buildingschoolb, don't eat rice.

C. Wisdom from Doing Ngrowot Tirakat According to Santri Jagad 'Alimussirry islamic buildingschool who is currently and when doing Ngrowot

The Jagad 'Alimussirry islamic buildingschool for students, apart from being taught the science of Islamic law, includes issues of Fiqh, morals and the science of the Qur'an hadiths. But also taught Sufism accompanied by practices of riyadhoh and tirakatnya. The Tirakatan itself is in the form of tasks from KH's brother. Djoko Hartono, S.P.d, S.Ag, MM as the main director of the Jagad 'Alimussirry islamic buildingschool student. Currently, almost all students do penance because it is also a requirement to pass this buildingschool. One of the Riyadhohs that many students do is fasting 3 days by practicing wazifa. The students who do tirakat ngrowot are those who have been doing tirakatan for a long time, a number of 5 female santri who will represent the respondents in this study.

Remembering Allah is the source of the health of the heart and soul, on the other hand, forgetting is the peak of heart and soul disease, as well as calamity for human life. With riyadhoh, the students will remember Allah more because riyadhoh contains wirid, dhikrdhikr to Allah with the aim of getting closer to Allah SWT.

As for the Tirakatan for the santri, it is something that is done to serve the kyai, for the task he has been given. One of his duties is ngrowot (not eating rice or white rice) to control lust and liver disease. The nafs (selfaccording to Frager) is one of the aspects of psychology that starts from our worst hostility but which can then be developed as a valuable tool. In Frager's view, this nafs has seven levels; starting with anger and ending with pure lust (al - nafs al - Mahdh). The attainment of these levels can be achieved through striving (mujahada), training or spiritual discipline (riyadhoh) and seeing oneself in others.

Ngrowot is a tradition that is carried out by the Jagad 'Alimussirry islamic buildingschool with certain objectives such as: advice for inner strengthening, symbols of concern, and others. Ngrowot fasting has its own uniqueness and characteristics, namely not in the experience that a person is not allowed to consume rice, there is no opening and suhoor, the perpetrators of ngrowot fasting are allowed to eat daily only food made from other than rice (Suyadi, 2018).

"At the beginning, I did 1 ulan 2 ulan abot, when 3 ulan 4 ulan wes uenak was actually healthier than arek lio, instead I was more excited than arek lio ..." (MA. Santri. 17 April 2020) So, because of habit eating that is initially white rice or rice-based, the perpetrators of tirakat ngrowot who do it for the first time feel heavy at the beginning, but over time they will get used to it and generate a sense of enthusiasm in living life.

Ngrowot is a practice of riyadhoh as a form of zuhud behavior, which is to let go of dependence on worldly or material dependence. Sufis teach not to depend on worldly things through this spiritual teaching, one is taught to achieve blessings and happiness that are eternal, because positive feelings do not arise from worldly things but from a calm heart (Martokusumo, 2011) .

"There are so many, the problem is that if the rice is different, I will stick with different patience, so if you go outside, you don't want to do it carelessly, you hold more se and iku because of your patience and maturity. because of patience, and easier understand people, for example when you meet people, 
you don't immediately judge, you are more prone to having a global perspective, then you continue to stick, for example, you hurt when you wait, yo humane yo we get angry but when we get angry, I don't want to be more open, and we get a teapot liver diseases. The spirit of worship, the determination is higher and the ambition is higher ". (MM. Santri. April 14, 2020). From there it can be concluded that what is eaten affects one's appetite and behavior. And also can get closer to Allah SWT.

Jagad 'Alimussirry islamic boarding school has a motto, namely:

1. Don't die (don't fear death)

2. Not wedi lue (not afraid of being hungry)

3. Not wedi loro (not afraid of getting sick)

4. No worried (not afraid of being poor)

5. Not wedi diilokno (not afraid of being insulted)

6. Not arep - arep (not expecting something)

Jagad 'Alimussirry Islamic

Buildingschool's motto is also a measure of the mental calmness of ngrowot behavior.

According to MS doing tirakatan ngrowot can apply the motto Jagad 'Alimussirry islamic buildingschool and MS can increase Jagad 'Alimussirry Islamic Building school's Motto: No wedi lue by $40 \%$, No wedi lue by $40 \%$, No wedi loro by $90 \%$, No wedi die by $40 \%$, No wedi diilokno as big as $90 \%$, not arep - arep or nJagad 'Alimussirry buildingschoolgakno at $100 \%$. (MS. Santri. April 13, 2020). What you eat can affect your lust and behavior, so it can increase your peace of mind because you are close to Allah SWT. As explained above, ngrowot behavior is part of worship that can get closer to Allah SWT. As stated in the Al - Quran "And when my servants ask you about me, then (answer), that I am near. I grant the request of the person who prays when he asks Me. So let them fulfill (all My commandments) and let them have faith in Me, so that they will always be in the truth "(Surah Al Baqrah: 186).

"Bien, when I graduated from my IPK, was considered the lowest, but my pass was the fastest between my koncoku and ISO, I went straight to my S2, especially when I got my S2 I signed up for AU moro - moro was immediately attracted and my koncoku pushed entok kerjoan, then when I graduated from S2 I made it easier". (MR. Ustadzah. 15 April 2020).

Tirakat ngrowot is an effort to get closer to Allah SWT so that it makes the heart calm and all matters of life will be made easier and streamlined by Him.

\section{CONCLUSION}

1. Santri Ponpes Jagad 'Alimussirry islamic buildingschool students do tirakat ngrowot sincerely and are happy to carry out the duties of the kyai's brother.

2. Initial conditions or problems experienced by students of the Jagad 'Alimussirry islamic buildingschool are problems of responsibility, campus and cottage environment problems.

One of the impacts that can be seen during or after doing tirakat ngrowot is being a person who is resilient, patient, and can apply the Jagad 'Alimussirry Islamic Building School motto in everyday life. And also getting blessed to leave as it is facilitated in education and looking for work.

\section{REFERENCES}

[1] Asmaran As, Introduction to Moral Studies, (Jagad 'Alimussirry building school, wali Pers, 1992), p. 228

[2] Darajat, Zakiah. The role of religion in mental health, (Jakarta; Gunung Agung, 1982), p. 79.

[3] Darajad 'Alimussirry buildingschoolt, Zakiyah. Happiness. Jakarta: Ruhama Islamic Education Foundation, 1990.

[4] DEPDIKBUD, Big Indonesian Dictionary (Jagad 'Alimussirry buildingschoolkarta, Balai Pustaka, 1996), 2nd Edition, cet. 7th, p. 416. 
[5] Fragger, Robbert. Heart, Self, and Spirit: Sufi Psychology for Transformation. Jagad 'Alimussirry buildingschoolkarta: Serambi, 1999.

[6] Haris Herdiansyah, Qualitative Research Methodology: For Social Sciences, (Jagad 'Alimussirry buildingschoolkarta: Salemba Humanika, 2012), pp. 18.

[7] Hartono, Djoko.2018. Amaliyah Thariqat Jagad 'Alimussirry. Surabaya: Jagad 'Alimussirry buildingschool

[8] Hawwa, S. 2002. Intisari Ihya 'Ulumuddin Al Ghazali: Purifying the soul. Jagad 'Alimussirry buildingschoolkarta: Rabbani Press)

[9] Jagad 'Alimussirry buildingschoollaluddin, DR, and Zen, Ali Ahmad, Dictionary of Mental Science and Education, Surabaya: Putra Al - Ma'arif, 1995.

[10] Kartini Kartono and Jenny Andari, Mental Hygiene and Mental Health in Islam, (Bandung: Mandar Maju, 1989) p. 4.

[11] Martokusumo, Prianto H, and David Wattimena. 2011. Spiritual Happinss. Bandung: Mizan Pustaka.

[12] Nietsche ,. F 1998 Beyond good and evil. Oxford University Presss New York.

[13] Prawiroatmojo, Bausastra Jawa - Indonesia (Surabaya: Haji Masagung 1992) p. 482.

[14] Sugiyono, Quantitative Research Methods, Qualitative, and R \& D, (Bandung: Alfabeta, 2011), pp. 85.

[15] Suyadi. Ngrowot Culture in Neuroscience Studies in Islamic BuildingSchools

[16] Interpretation Team of the Ministry of Religion of the Republic of Indonesia. 1991. Al - Quran and its interpretation. Yogyakarta: UII Waqf Board. 